\title{
The impact of observation nudging on simulated meteorology and ozone concentrations during DISCOVER-AQ 2013 Texas campaign
}

\author{
Xiangshang Li ${ }^{1}$, Yunsoo Choi ${ }^{1}$, Beata Czader ${ }^{1}$, Anirban Roy ${ }^{1}$, Hyuncheol Kim ${ }^{2,3}$, Barry Lefer ${ }^{1}$, and Shuai Pan ${ }^{1}$ \\ ${ }^{1}$ Department of Earth and Atmospheric Sciences, University of Houston, Houston, TX, 77204, USA \\ ${ }^{2}$ NOAA Air Resources Laboratory, College Park, MD 20740, USA \\ ${ }^{3}$ University of Maryland, Cooperative Institute for Climate and Satellite, College Park, MD, USA
}

Correspondence to: Xiangshang Li (xli@ central.uh.edu)

Received: 17 July 2015 - Published in Atmos. Chem. Phys. Discuss.: 9 October 2015

Revised: 10 January 2016 - Accepted: 7 February 2016 - Published: 9 March 2016

\begin{abstract}
Accurate meteorological fields are imperative for correct chemical transport modeling. Observation nudging, along with objective analysis, is generally considered a lowcost and effective technique to improve meteorological simulations. However, the meteorological impact of observation nudging on chemistry has not been well characterized. This study involved two simulations to analyze the impact of observation nudging on simulated meteorology and ozone concentrations during the 2013 Deriving Information on Surface conditions from Column and Vertically Resolved Observations Relevant to Air Quality (DISCOVER-AQ) Texas campaign period, using the Weather Research and Forecasting (WRF) and Community Multiscale Air Quality (CMAQ) models. The results showed improved correlations between observed and simulated parameters. For example, the index of agreement (IOA) improved by about $9 \%$ for surface temperature and 6-11\% for surface zonal (U-WIND) and meridional (V-WIND) winds when observation nudging was employed. Analysis of a cold front event indicated that nudging improved the timing of wind transition during the front passage. Observation nudging also reduced the model biases for the planetary boundary layer height predictions. Additionally, the IOA for CMAQ simulated surface ozone improved by $6 \%$ during the simulation period. The high-ozone episode on 25 September was a post-front ozone event in Houston. The small-scale morning wind shifts near the Houston Ship Channel combined with higher aloft ozone early morning likely caused the day's ozone exceedance. While observation nudging did not recreate the wind shifts on that day and failed to reproduce the observed high ozone, analyses of surface and aircraft data found that observation nudging helped
\end{abstract}

the model yield improved ozone predictions. In a $2 \mathrm{~h}$ period during the event, substantially better winds in the sensitivity case noticeably improved the ozone. The average IOA for ozone in the period increased from just over 0.4 to near 0.7 . Further work on improving the capability of nudging to reproduce local meteorological events such as stagnations and wind reversals could enhance a chemical transport model's skill for predicting high-ozone events.

\section{Introduction}

Meteorological variables such as cloud fraction, winds, planetary boundary layer (PBL) heights, and precipitation significantly impact air quality. They influence the production, transport, and deposition of various chemical species (e.g., Banta et al., 2005; Pour-Biazar et al., 2007; Cuchiara et al., 2014). Hence accurate meteorological inputs are imperative for air quality modeling. Common approaches of improving meteorological simulations include the selection of updated and high-resolution terrain data (e.g., Cheng and Byun, 2008), optimization of physics and dynamics options (e.g., Zhong et al., 2007), and the implementation of 4-D data assimilation (FDDA) (e.g., Stauffer and Seaman, 1994).

FDDA continuously merges new observational data into model simulation such that the model predictions do not drift away from observations. There are several FDDA methods including nudging (e.g., Stauffer and Seaman, 1994) and variational methods (3D-VAR or 4D-VAR; e.g., Le Dimet and Talagrand, 1986; Huang et al., 2009). 4D-VAR obtains optimal states of the atmosphere using multi-time-level ob- 
servations by globally adjusting a model solution to all available observations over an interval of time. Nudging is a simple yet flexible FDDA method originally developed by Stauffer and Seaman $(1990,1994)$ and implemented in the fifthgeneration PSU/NCAR mesoscale model (MM5). Not intended for optimal adjustment, nudging is less computationally intensive but needs special care for the nudging coefficients. Nudging involves adding an artificial tendency term to one or more model prognostic equations that reflect the difference between the best estimate of the observed state and the model state at a given location and time. In short, the goal is to "nudge" the model state towards the observed state. There are several types of nudging such as 3-D analysis nudging, surface analysis nudging, and observation nudging (obs-nudging). In the case of analysis nudging, the model state is nudged toward gridded analysis. The difference between 3-D and surface analysis nudging is that 3-D analysis (at all model levels except for surface) data are used in 3$\mathrm{D}$ analysis nudging to improve 3-D fields, while in surface analysis nudging only surface analysis is used to improve surface fields. In observation nudging, the model predictions are nudged to match better with observations at individual locations both on the surface and aloft. The MM5 nudging codes were later improved and incorporated into the Weather Research and Forecasting (WRF) model by Liu et al. (2005, 2006). The enhancements enable obs-nudging to assimilate a large variety of direct or derived observations. In WRF, the inputs for obs-nudging are generated by the WRF OBSGRID program. This program also performs objective analysis (OA) to improve the quality of analysis nudging files. OA updates first guess meteorology analysis by incorporating observational data. Since obs-nudging is usually performed along with OA (as in this study) to maximize the benefits of assimilating observations, we also use OA to denote the combined objective analysis and obs-nudging processes in case names.

The benefit of applying nudging to improve meteorological simulations has been demonstrated by several studies (e.g., Deng et al., 2009; Gilliam and Pleim, 2010; Rogers et al., 2013). However, the impact of the improved fields on air quality simulations has been investigated by relatively fewer studies. Otte (2008) showed that the Community Multiscale Air Quality (CMAQ) model with improved MM5 meteorology using analysis nudging was able to better simulate ozone chemistry as reflected in model-measurement statistics. Their results indicated that better "model skill" scores were achieved for daily maximum $1 \mathrm{~h}$ ozone mixing ratios after analysis nudging over a 35-day simulation episode. Byun et al. (2008) performed over a dozen tests on obs-nudging (with analysis nudging turned on) and showed obs-nudging improved both winds and temperature in the MM5 simulations. The study also gave an example in which improved wind fields on a given day helped the CMAQ model better capture the ozone hotspot southwest of Houston. Ngan et al. (2012) compared results from several CMAQ simula- tions coupled to the MM5 model. Their results indicated that fully nudged simulations (with both analysis nudging and obs-nudging implemented) performed better than a forecast one with respect to both meteorology and ozone chemistry. However, the statistics from their study cannot be used for interpreting the sensitivity of obs-nudging since its base case is a forecast run which used a different analysis input. Previous studies by the current authors (e.g., Rappenglück et al., 2011; Czader et al., 2013) showed that obs-nudging helped correct errors in model wind fields, critical to the transport of pollutants and production of secondary pollutants. To the best of the authors' knowledge, there is no comprehensive study on the impact of obs-nudging on air quality simulations using the WRF model.

This study intends to fill up the gap in the studies mentioned above by investigating the sensitivity of WRF and subsequently CMAQ simulations to observation nudging. In theory, higher frequency of obs-nudging input should have a higher likelihood to capture small-scale events such as local wind shifts. These events may only slightly impact local weather, yet they have a marked effect on chemistry. This is because local stagnation and wind convergence/reversals can contribute to the pollutant build-up, as indicated by Banta et al. (1998), Cheung and Wang (2001), and Tucker et al. (2010).

There is a significant presence of petrochemical facilities, power plants, and motor vehicles in the HoustonGalveston-Brazoria (HGB) region located in southeastern Texas (SETX). The major pollutant in the region is ozone due to the abundant emissions of precursors like nitrogen oxides $\left(\mathrm{NO}_{x}\right)$ and volatile organic compounds (VOCs). Summertime ozone concentrations often rise above the National Ambient Air Quality Standard (NAAQS). Consequently, HGB has been designated as an ozone nonattainment region by the US Environmental Protection Agency (USEPA) (http://www3.epa.gov/ airquality/greenbook/hncs.html\#TEXAS). The petrochemical plants are largely concentrated in the Houston Ship Channel (HSC) area, just north of the Galveston Bay. The VOCs emitted from the HSC area are highly reactive and have been shown to contribute greatly to the high regional ozone episodes (e.g., Kleinman et al., 2002; Daum et al., 2004). Depending on the local meteorology, the plumes from HSC may be carried to different locations in HGB and trigger highozone events in its path. Metropolitan Houston has a high level of $\mathrm{NO}_{x}$ emissions partly due to heavy urban vehicular traffic. As a result, relatively frequent high-ozone events occur in the area.

Due to the reasons listed above, the HGB region has been the focus of several air quality studies in the recent past (e.g., Banta et al., 2005; Parrish et al., 2009; Olaguer et al., 2009; Lefer and Rappenglück, 2010; Czader etal., 2013; Choi et al., 2012; Choi, 2014; Choi and Souri, 2015; Pan et al., 2015). It is a good place for studying ozone production and transport due to the existence of a 
dense surface monitoring network as well as several intensive measurement field campaigns which provide ample observational data. For example, in September 2013 the National Aeronautics and Space Administration (NASA), joined by a number of agencies and universities, conducted a field measurement campaign in SETX as part of its the Deriving Information on Surface conditions from Column and Vertically Resolved Observations Relevant to Air Quality (DISCOVER-AQ) program (http://www-air.larc. nasa.gov/missions/discover-aq/discover-aq.html). This program has conducted several air quality and meteorology measurements at different locations in the USA. The availability of dense surface observations is important for obs-nudging to correct erroneous local winds in the model. The performance of obs-nudging would be handicapped without a rich set of observations.

This study involved performing two sets of WRF and CMAQ model simulations for the 2013 DISCOVER-AQ Texas time period in order to understand the impact of obsnudging. The data for nudging included multiple sets of observation data from both surface and aloft measurements. We evaluated model-measurement performance statistics for both WRF and CMAQ output. The paper is structured as following: Sect. 1 is introduction; Sect. 2 describes the measurement data and the modeling system; Sect. 3 covers the evaluation protocols; Sect. 4 discusses the general meteorological conditions during the campaign period; Sect. 5 presents the modeling results; and Sect. 6 provides discussions and conclusions.

\section{Observational data and model configurations}

\subsection{Observational data}

This study used regular measurements from the continuous ambient monitoring stations (CAMS) operated by the Texas Commission on Environmental Quality (TCEQ). Additionally, PBL and aloft ozone measurement data were obtained from the DISCOVER-AQ campaign. For observation nudging, CAMS data and several data streams from the Meteorological Assimilation Data Ingest System (MADIS) were used. The CAMS measurement network collected real-time meteorology and pollutant data. The measured parameters differ from station to station. The station density at SETX is relatively high. There were 63 and 52 sites with meteorological and ozone measurements, respectively, in the $4 \mathrm{~km}$ domain. The network is represented in Fig. 1. The sites are represented by dots, with the La Porte (C556) site labeled. All CAMS observations are accessible online at the TCEQ website: http://www.tceq.state.tx.us/cgi-bin/ compliance/monops/daily_summary.pl.

Additionally, PBL height measurements for September were recorded at a site at the University of Houston main campus. The PBL height was measured using the light de-

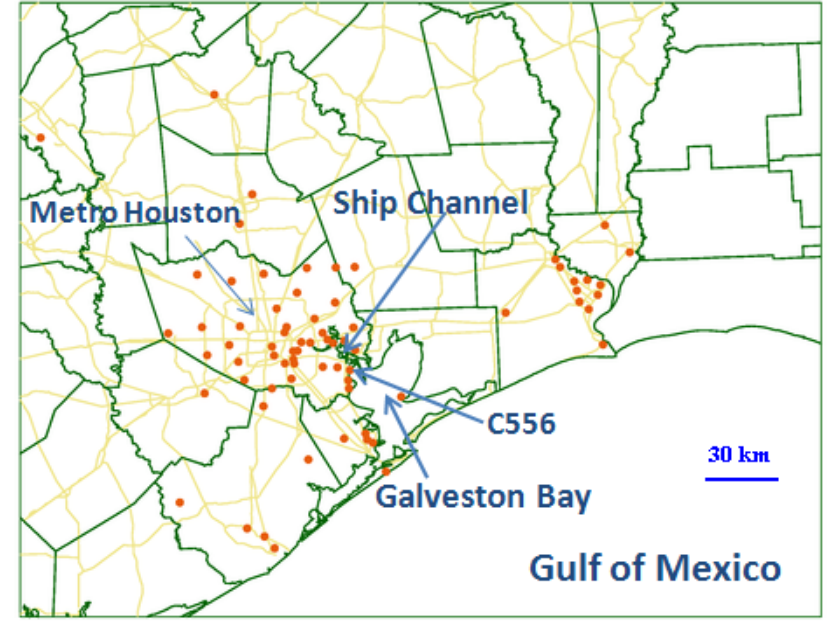

Figure 1. Locations of CAMS sites (dots) in CMAQ $4 \mathrm{~km}$ modeling domain during September 2013. Metro Houston, Houston Ship Channel, Galveston Bay, and Gulf of Mexico are labeled.

tection and ranging (lidar) system. The PBL data is currently available only at this site. Primarily due to a significant number of cloudy days, the PBL data coverage is incomplete (about $50 \%$ ). For analysis of aloft ozone, we also used measurements from the $\mathrm{P}-3 \mathrm{~B}$ aircraft, which is part of the rich data sets collected during DISCOVER-AQ campaign. The $\mathrm{P}$ 3B data had over 100 parameters which are accessible online.

\subsection{Model configurations}

The modeling system consists of the WRF meteorological model (Skamarock et al., 2008), the Sparse Matrix Operator Kernel Emissions (SMOKE) model for emissions modeling (Houyoux et al., 2000), and the CMAQ model (Byun and Schere, 2006) for chemical transport modeling. The details about model configurations are presented in the following sections. Two sets of simulations were conducted, one set with obs-nudging and OA and the other without. The base case, referred as "No-OA", did not employ obs-nudging or OA. The second case, "1Hr-OA", performed obs-nudging and OA using hourly nudging input.

\subsubsection{WRF setup}

Both WRF simulations used the same nested domain and NARR (North American Regional Reanalysis) as input, with grid nudging turned on. Figure 2 depicts the horizontal domain setup. Two nested domains were used, with 12 and $4 \mathrm{~km}$ resolution, respectively. The $4 \mathrm{~km}$ domain covered SETX and a small portion of Louisiana. The $12 \mathrm{~km}$ domain (red box) encompassed Texas and parts of a few neighboring states. The number of grid cells for the 12 and $4 \mathrm{~km}$ domains were $161 \times 145$ (E-W by N-S), and $95 \times 77$, respectively. The projection type was Lambert conic conformal. Three projection parameters, first latitude $\left(33^{\circ} \mathrm{N}\right)$, second latitude 
Table 1. Major WRF physics and FDDA options; the numbers in the parentheses are the related settings in WRF namelist file.

\begin{tabular}{ll}
\hline WRF version & V3.5.1 \\
\hline Microphysics & Lin et al. scheme (1983) \\
Long-wave radiation & RRTMG (rapid radiative transfer model for general circulation models), Iacono et al. (2008) \\
Shortwave radiation & New Goddard scheme, Chou and Suarez (1999) \\
Surface layer option & Monin-Obukhov with Carlson-Boland viscous sublayer scheme (1978) \\
Land-surface option & Unified Noah LSM, Chen and Dudhia (2001) \\
Urban physics & None \\
Boundary layer scheme & YSU, Hong et al. (2006) \\
Cumulus cloud option & Kain-Fritsch (2004) \\
FDDA & Grid nudging on for all; observation-nudging on for the OA case \\
\hline
\end{tabular}

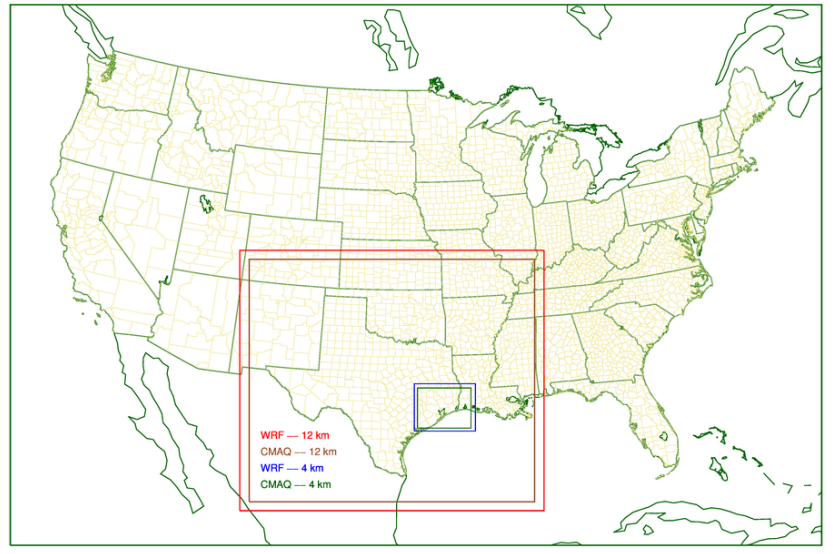

Figure 2. Horizontal domains of WRF and CMAQ simulation at 4 and $12 \mathrm{~km}$ grid resolution (the bigger domains are for $12 \mathrm{~km} \mathrm{WRF}$ and CMAQ and the smaller domains for $4 \mathrm{~km}$ WRF and CMAQ).

$\left(45^{\circ} \mathrm{N}\right)$, and standard longitude $\left(97^{\circ} \mathrm{W}\right)$, are conformal to the projection parameters used by the USEPA in developing emission inventories for air quality modeling (Mason et al., 2010). Both domains had a vertical resolution of 27 eta layers based on dry hydrostatic pressures. The model top is $100 \mathrm{hPa}$, corresponding to top layer pressure of the input NARR data.

\section{Input data}

The NARR data used for WRF simulations are downloadable from http://rda.ucar.edu/datasets/ds608.0/. The data were based on an Eta 221 grid at 29 pressure levels. Its horizontal resolution was $32 \mathrm{~km}$ and the frequency was 3 hourly. The initial and boundary conditions were generated from the NARR analysis by WRF Pre-Processing System (WPS). An alternative to NARR was the Eta-NAM analysis data. However, the data temporal frequency was lowered from 3 hourly to 6 hourly starting in 2013. Our tests showed that it was not as good as the NARR data set - likely because of lower temporal resolution.

\section{Physics and FDDA options}

Major physics options used in the model are listed in Table 1. Our past modeling experiences indicated that employing the Yonsei University (YSU) for the PBL scheme and the Kain-Fritsch $(\mathrm{K}-\mathrm{F})$ for the cumulous scheme gave the best results for the Houston area. The YSU scheme was also one of the two PBL schemes recommended by Cuchiara et al. (2014). The K-F scheme is "drier" than others and produces a smaller number of "false" convectional thunderstorms. For grid nudging options, we generally followed the recommendations in the WRF user guide. For example, the mass fields (temperature and moisture) were nudged only at layers above the PBL while wind fields were adjusted at all layers including the surface layer.

\section{Observation nudging with MADIS and CAMS data in WRF}

Additional observational data are required to implement obsnudging and OA. To generate the input files for the OBSGRID program, we processed the observation data using the approach of Ngan et al. (2012) and Czader et al. (2013). Observational data were taken from the MADIS and TCEQ CAMS. MADIS is a National Oceanic and Atmospheric Administration (NOAA) program which collects, integrates, quality-controls, and distributes observations from NOAA and other organizations. Additional information is available online at https://madis.ncep.noaa.gov/. The four MADIS data sets used for obs-nudging were NOAA Profiler Network (NPN), Cooperative Agency Profilers (CAP), Meteorological Terminal Aviation Routine (METAR) weather report, and NOAA radiosonde (RAOB). The METAR data set was collected by mostly first-order, METAR reporting, surface monitoring stations. NPN, RAOB, and CAP were the most commonly used upper air data sets.

The processed input observation data were fed into OBSGRID to update the domain analyses and generate additional surface analyses and text nudging files. Obs-nudging was performed by the main WRF program after obs-nudging namelist variables are properly set. The namelist for OBS- 
Table 2. Major CMAQ options; the text in the parentheses indicates the related settings in CMAQ build script.

\begin{tabular}{ll}
\hline CMAQ version & V5.0.1 \\
\hline Chemical mechanism & CB05 gas-phase mechanism with active chlorine chemistry, updated toluene mechanism, \\
& fifth-generation CMAQ aerosol mechanism with sea salt, aqueous/cloud chemistry \\
Lightning NO $_{x}$ emission & Included inline \\
Horizontal advection & YAMO (Yamartino) \\
Vertical advection & WRF omega formula \\
Horizontal mixing/diffusion & Multiscale \\
Vertical mixing/diffusion & Asymmetric Convective Model (ACM) version 2 \\
Chemistry solver & EBI (Euler backward iterative) \\
Aerosol & AERO5 for sea salt and thermodynamics \\
Cloud option & ACM cloud processor for AERO5 \\
Boundary conditions & Default static profiles \\
\hline
\end{tabular}

GRID and relevant WRF section settings came largely from recommended values of the WRF user guide and a previous study by Ngan et al. (2012).

Theoretically, obs-nudging updating at a higher frequency should enhance the model's performance. A typical frequency of input analysis data is 3 hourly while the frequency for observational data is hourly. The 3-hourly frequency of input analyses may be the reason for the default $3 \mathrm{~h}$ time interval in WRF's OBSGRID settings for generating the obsnudging files. Since there were few existing obs-nudging studies related to air quality and we were not aware of any reference to the adoption of a $1 \mathrm{~h}$ input frequency, we assumed that all previous studies used the default $3 \mathrm{~h}$ interval. As the WRF model allows the interval to be set to $1 \mathrm{~h}$ or smaller when corresponding observational data were available, we tested both 1 and $3 \mathrm{~h}$ scenarios. The results indicated that $1 \mathrm{~h}$ obs-nudging had slightly better performance than the $3 \mathrm{~h}$ one. As a result, this study adopted $1 \mathrm{~h}$ temporal frequency for observation nudging. The variables that were nudged were temperature, moisture, and the two wind components (zonal U-WIND and meridional V-WIND). Obsnudging for moisture was not performed in this study. This was based on our past experiences since performing moisture nudging sometimes triggers excessive artificial thunderstorms, which disrupted the model flow fields.

\subsubsection{Emissions processing}

For anthropogenic sources we utilized the USEPA's National Emissions Inventory of 2008 (NEI2008). Motor vehicle emissions for this inventory were processed using the USEPA's Motor Vehicle Emissions Simulator (MOVES) model (USEPA, 2015). The inventory was processed using the SMOKE model v3.1 (Houyoux et al., 2000) to obtain gridded emission rates and speciated for the Carbon Bond 05 (CB05) chemical mechanism for use in the CMAQ model. The biogenic emissions were modeled using the Biogenic Emissions Inventory System (BEIS) v3.14. Although NEI2008 might have overestimated $\mathrm{NO}_{x}$ emissions in Hous- ton (e.g., Choi, 2014; Czader et al., 2015), we used base NEI2008 without adjustment because the adjustment of the $\mathrm{NO}_{x}$ emissions also has large uncertainty (Czader et al., 2015). Pan et al. (2015) showed that the CMAQ ozone performance using NEI2008 appeared reasonable.

\subsubsection{CMAQ configurations}

The USEPA's CMAQ (Byun and Schere, 2006) version 5.0.1 was adopted for this study. Several air quality studies focusing on the Houston area have used this model (e.g., Foley et al., 2010; Czader et al., 2013, 2015; Choi, 2014; Pan et al., 2015; Diao et al., 2016; Souri et al., 2016). The model's horizontal domains were slightly smaller than its WRF counterpart in order to avoid the discontinuity near the domain boundary. The domains are depicted in Fig. 2 as green and brown boxes. The chemical boundary conditions for all the species in the $4 \mathrm{~km}$ domain were derived from the $12 \mathrm{~km}$ domain air quality forecasting results, available online at http://spock.geosc.uh.edu. The model used the same vertical structure as WRF. Additional model configurations are listed in Table 2. Chemical processes were simulated with the CB05 chemical mechanism with cloud/aqueous chemistry, active chlorine chemistry, and an updated toluene mechanism. For aerosol modeling, the fifth-generation CMAQ aerosol mechanism (AERO5), which includes sea salt modeling, was selected. The total number of included species is 132 , with 70 reactive gas-phase, 49 aerosol, and 13 nonreactive species.

\section{Evaluation metrics}

To assess model performance against observations, we computed a set of five statistics including Pearson correlation, index of agreement (IOA; Willmott 1981), mean bias (MB), root mean square error (RMSE), and mean absolute error (MAE). This list is similar to one used by $\mathrm{Li}$ et al. (2008) for model performance evaluation. The goal is to have a com- 


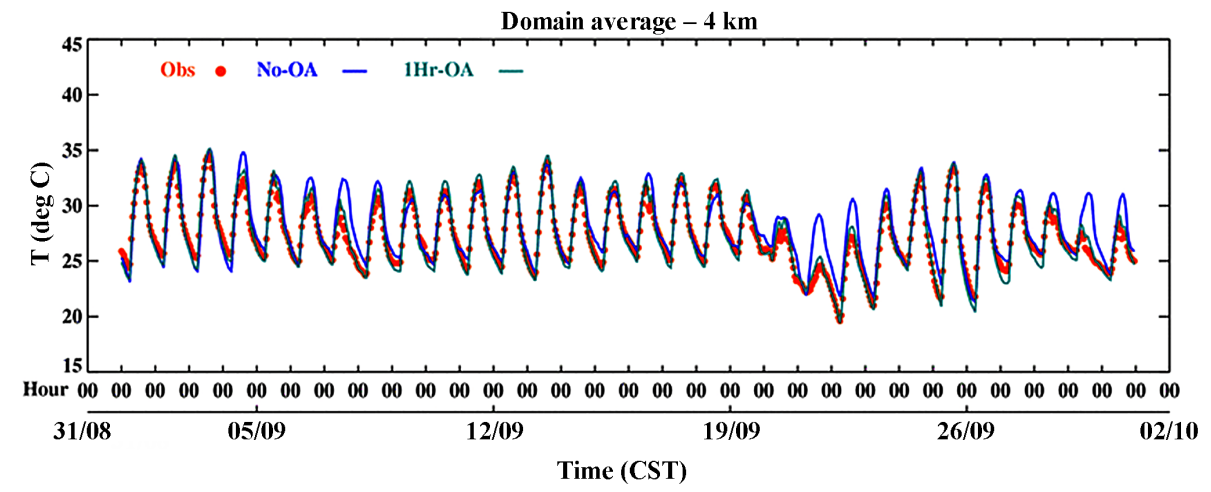

Figure 3. Regional hourly temperature averaged over all available hourly CAMS observations; two model cases are also included for September of 2013.

prehensive comparison between model and observation time series. The set of five statistics was divided into three groups.

1. Evaluation of the magnitude of model results vis-a-vis in situ data, in measurement units;

- MB,

- MAE, and

- RMSE.

2. Measuring how close the model values follow changes in the observations, unitless;

- correlation.

3. A composite performance index, index of agreement (IOA or d), unitless.

IOA is considered a better performance index than correlation as it takes into account the difference in the means and standard deviation. For example, when correlations are similar, lower model biases would yield higher IOA values. Additionally for this study, the mean and the standard deviation of model values and observations were included as a reference.

\section{General meteorological and ozone conditions in September 2013}

The weather during September 2013 was relatively dry with mostly southerly, easterly, or southeasterly winds. From 5 to 19 September, there was a lack of influence of strong synoptic weather systems. Shifting wind patterns were observed during the period: light northeasterly in the early morning gradually turned clockwise to southeasterly in the afternoon and evening hours. In this period, winds shifted from southeast to near east and there were more clouds after 10 September. The only cold front arrived on the early morning of 21 September. Figure 3 shows the regional average temperatures for the period and it can be seen that 21 September had the lowest daily maximum temperature. The influences of the cold air intrusion lasted until early 21 September. Winds turned into southerly in the afternoon of 25 September and warming continued in the next few days until 28 September.

Light rain events occurred on 2,10,16, 19 to 21, and 28 to 30 September. Events on 20 and 21 September consisted of widespread light to medium showers. Besides the above-mentioned dates, there were a few other days with sporadic drizzles. A majority of the days between 1 and 20 September were either sunny or cloudy. The periods from 8 to 10 September and 18 to 20 September had more clouds than other days. The period from 21 to 30 September was influenced by a cold front passage. The days between 22 and 24 September were sunny and cold. The surface wind reversed direction during midday of 25 September and brought clouds back from 26 to 30 September. High-ozone events in SETX during fall are typically associated with the passage of a cold front (e.g., Rappenglück et al., 2008). The only ozone event with hourly surface ozone exceeding $120 \mathrm{ppb}$ (parts per billion) in September which occurred on 25 September fell in this category.

Figure 4 plots the hourly regional averaged ozone. On most days, the in situ averaged ozone concentrations were below $70 \mathrm{ppb}$. Since the winds after dawn consistently pushed the precursors from the industrial area to the southwest of the city, the wind pattern did not favor the local ozone production. The daytime winds also contained a persistent easterly component which moved the pollutants away from the Houston metropolitan area. In the first 10-day period, low background ozone originating from the Gulf of Mexico contributed to the low-ozone days. With overcast skies on 19 and 20 September, hourly high-ozone values dipped below $30 \mathrm{ppb}$. The two highest-ozone days characterized by post-frontal ozone events were 25 and 26 September.

\section{Results}

To evaluate the WRF simulation, we calculated statistics for surface temperature and winds in the $4 \mathrm{~km}$ domain. In addi- 
Table 3. Statistics of surface $T$, U-WIND, and V-WIND for three WRF simulations: $N$ refers to data points, Corr to correlation, IOA to the index of agreement, RMSE to the root mean square error, MAE to the mean absolute error, MB to the mean bias, $\mathrm{O}$ to observation, M to model, O_M to observed mean, M_M to model mean, and SD to standard deviation. Units for RMSE/MAE/MB/O_M/M_M/O_SD/M_SD: temperature, ${ }^{\circ} \mathrm{C}$; winds $(U$ and $V), \mathrm{m} \mathrm{s}^{-1}$.

\begin{tabular}{|c|c|c|c|c|c|c|c|c|c|c|}
\hline Case & $N$ & Corr & IOA & RMSE & MAE & MB & O_M & M_M & O_SD & M_SD \\
\hline \multicolumn{11}{|c|}{ Surface temperature $T$} \\
\hline No-OA & 41058 & 0.83 & 0.89 & 2.0 & 1.5 & 0.9 & 27.4 & 28.3 & 3.1 & 2.8 \\
\hline $1 \mathrm{Hr}-\mathrm{OA}$ & 41058 & 0.94 & 0.97 & 1.0 & 0.8 & 0.0 & 27.4 & 27.4 & 3.1 & 3.1 \\
\hline \multicolumn{11}{|c|}{ Surface $U$-WIND } \\
\hline No-OA & 43246 & 0.76 & 0.84 & 1.4 & 1.1 & -0.6 & -1.3 & -1.9 & 1.6 & 1.9 \\
\hline $1 \mathrm{Hr}-\mathrm{OA}$ & 43246 & 0.81 & 0.89 & 1.0 & 0.8 & -0.3 & -1.3 & -1.6 & 1.6 & 1.6 \\
\hline \multicolumn{11}{|c|}{ Surface $V$-WIND } \\
\hline No-OA & 43246 & 0.76 & 0.8 & 2.1 & 1.7 & 1.2 & 0.4 & 1.7 & 2.0 & 2.6 \\
\hline $1 \mathrm{Hr}-\mathrm{OA}$ & 43246 & 0.80 & 0.89 & 1.2 & 0.9 & -0.1 & 0.4 & 0.4 & 2.0 & 2.0 \\
\hline
\end{tabular}

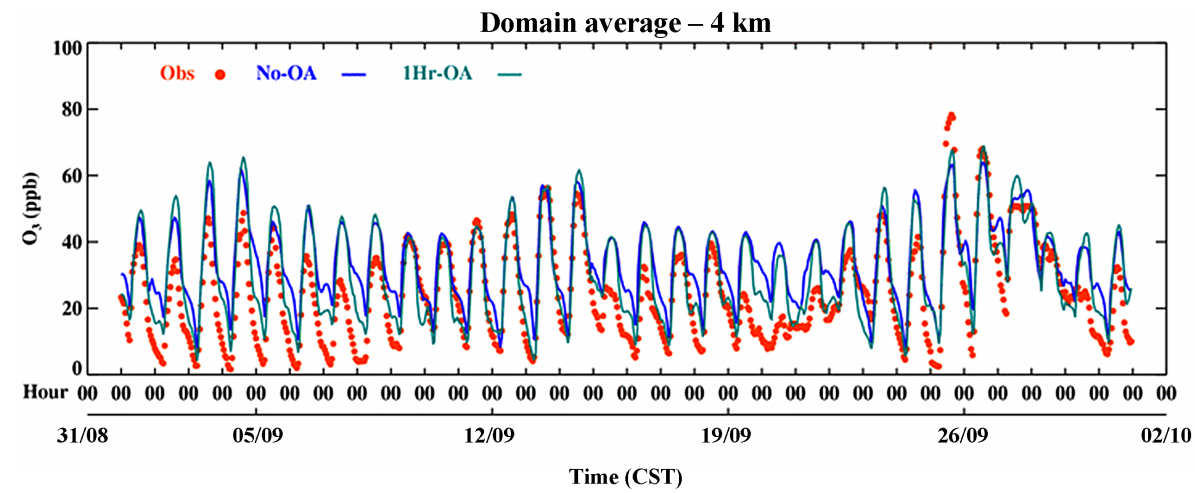

Figure 4. The hourly regional averaged ozone for the two cases (No-OA and 1hr-OA) at the stations which include observation surface $\mathrm{O}_{3}$ over the $4 \mathrm{~km}$ domain for September of 2013.

tion, we plotted out the PBL height time series for the one site for which we had observations. For CMAQ evaluation, we calculated the surface ozone statistics for the entire month. Also, we plotted vertical ozone profile and calculated biases for ozone aloft on 25 September.

\subsection{Meteorology}

\subsubsection{Temperature}

The comparison of regional average hourly temperature for the simulation period is shown in Fig. 3. The regional observed averaged surface temperature was calculated by averaging the hourly temperature from $\sim 60$ CAMS sites in the $4 \mathrm{~km}$ model domain. The base case temperature was too high compared to the in situ measurements. For example, the No-OA base case maximum temperature for the 21 September was $30^{\circ} \mathrm{C}$ compared to $25^{\circ} \mathrm{C}$ for the in situ data. The high biases in the base case are sharply reduced in the $1 \mathrm{Hr}-$ OA sensitivity case and temperature matched better with the observations for several time periods, especially for 20 to 23 September. The statistics of hourly surface temperature are listed in Table 3. With higher IOA and lower MBs, the $1 \mathrm{Hr}-\mathrm{OA}$ case was clearly better than the base case No-OA. The IOA of $1 \mathrm{Hr}-\mathrm{OA}$ was about $9 \%$ higher than the base case.

\subsubsection{Winds}

In ozone chemistry, winds affect the accumulation of precursors and hence the resulting ozone production (e.g., Banta et al., 2005, 2011; Darby, 2005). They are also responsible for dispersing high ozone and bringing in background ozone. Prevailing summer time southerly to southeasterly winds in the HGB region significantly lower the ozone concentrations in the metropolitan area. Therefore, high-ozone events usually occur when such wind patterns change. Cold front intrusions coming as early as late August blow pollutants to the south. As a result, an area of high ozone develops in the Gulf. Following cold fronts weakening and the weather warming up, reversing winds can bring high ozone back to 
land. High ozone may also occur during intra-day recirculation events when pollutants previously blown away from industrial zone are brought back by reversing winds. Correctly simulating these recirculation events is particularly important in predicting the high-ozone event caused by post-front conditions. The ozone event in the HSC area on 25 September was likely due to a combination of local recirculation caused by onset of the bay breeze and increased background ozone brought in by transport.

Due to the land-water thermal contrast and the different size of the Galveston Bay and the Gulf of Mexico, the western shore of the Galveston Bay often experiences a successive onset of bay breeze and sea breeze in the summer. The bay breeze is typically a weaker easterly while the sea breeze is a stronger southeasterly. The sea breeze usually arrives 1 to a few hours later after the bay breeze. The bay breeze and the subsequent sea breeze phenomena in Houston were described by Banta et al. (2005).

The statistics of U-WIN and V-WIND wind components are listed in Table 3. The purpose of choosing $U$ and $V$ over wind speed and direction is to avoid the anomalies in the wind direction statistics. For example, although the wind direction of 5 and $355^{\circ}$ are close, the statistics suggest that they are distinctively different.

For both $U$ and $V$ components of wind, 1Hr-OA had higher correlation and IOA than No-OA. The model performance on $U$ and $V$ are similar, with the correlation in a range of 0.76 to 0.81 for all the cases. For comparison, the performance of the OA case ("M1") in Ngan et al. (2012) is very close to that in this study, with a correlation of 0.75 for $U$ and 0.82 for $V$. In terms of IOA, the OA case is higher by $5-6 \%$ in $U$ and $10-11 \%$ in $V$ over the base case. This can be explained by the significantly reduced wind biases in the OA case.

The base case had consistently stronger winds, especially the southerly component, than the observations. This was reflected in the MB, as well as the model mean "M_M". Winds were reduced significantly after OA was performed. In fact, the high southerly bias in No-OA turned slightly negative after OA. Winds originating from the Gulf were also stronger in the base case, which played a role in raising the ozone level comparing to the $1 \mathrm{hr}-\mathrm{OA}$ sensitivity case. Figure 5 illustrated the slowing down of southerly winds after observation nudging. As a result of nudging, the wind vectors matched the observations better.

\subsubsection{PBL height}

Atmospheric pollutants are largely confined in the PBL as most of the emissions sources are close to the ground level. Hence the PBL height plays a critical role in mixing and spreading the pollutants. Haman et al. (2014) studied the relationship between ozone level and PBL height at a Houston CAMS site and found that nighttime and early morning PBL heights were consistently lower on high-ozone days
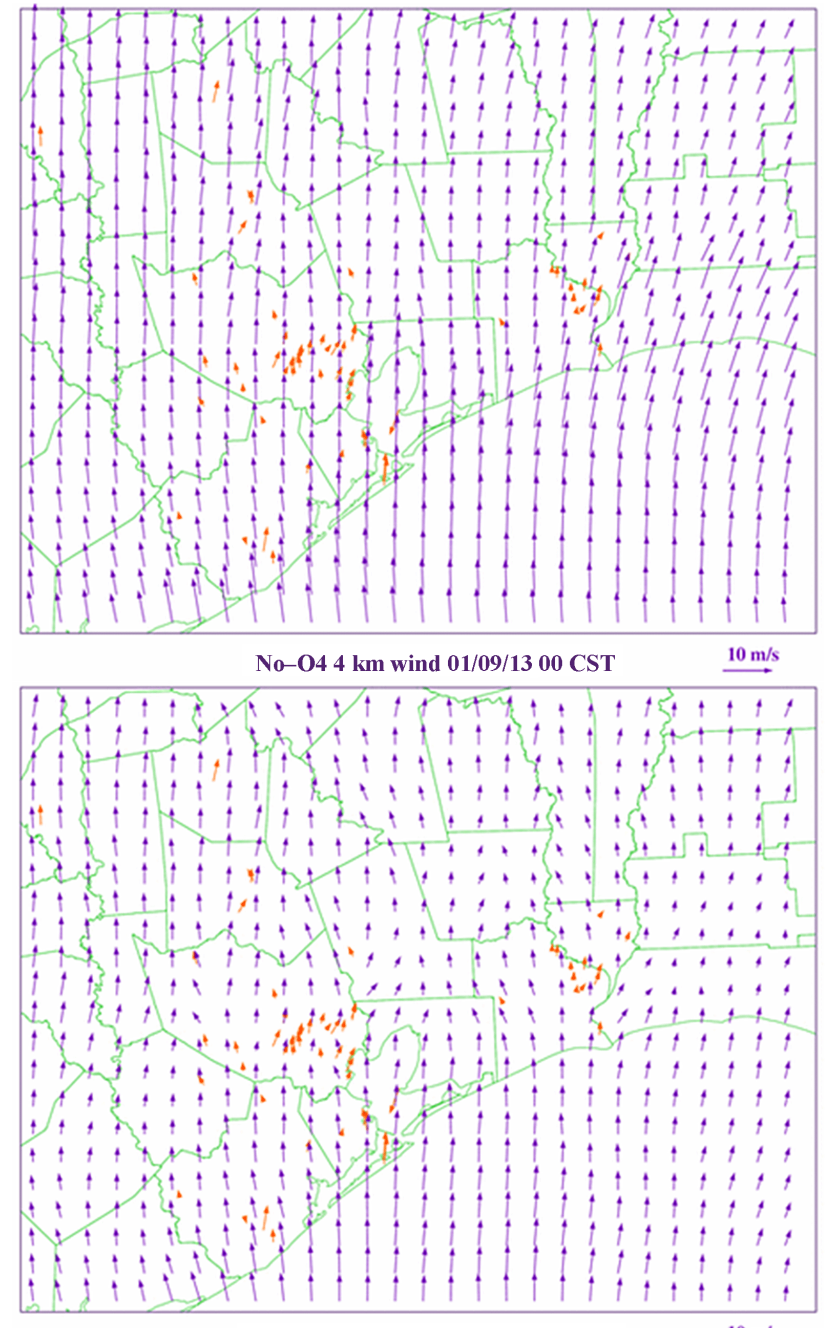

1Hr-OA 4 km wind 01/09/13 00 CST

$\stackrel{10 \mathrm{~m} / \mathrm{s}}{\longrightarrow}$

Figure 5. Model and observed winds on 1 September at 00:00 CST: No-OA (top panel) and 1 Hr-OA (bottom panel). Model winds are blue arrows and the observations are orange arrows. Stronger southerly winds, especially along coastal region, were reduced in the OA case.

than on low-ozone days. Czader et al. (2013) pointed out that the model underprediction of PBL during nighttime may have caused the $\mathrm{CO}$ overprediction at the same site. $\mathrm{CO}$ is a good proxy for understanding model transport since it has low reactivity and a relatively long lifetime in the troposphere (typically 2 months). Cuchiara el al. (2014) conducted four WRF/Chem sensitivity tests using different PBL schemes over southeastern Texas. While no preferred PBL scheme was identified for WRF simulations, the YSU scheme performed better than others in terms of ozone prediction. 


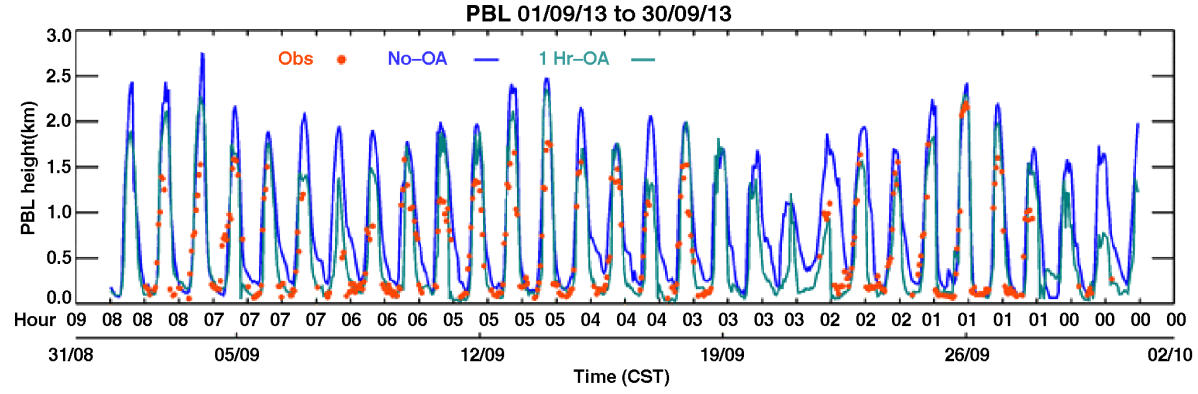

Figure 6. Planetary boundary layer (PBL) height time series at CAMS C695 for September 2013.

Haman et al. (2012) showed that the daily maximum PBL height at the University of Houston site mentioned in Sect. 2.1 reached its highest values of slightly over $2000 \mathrm{~m}$ in August. In September, typical daily maximum PBL height was $1500 \mathrm{~m}$ at 15:00 CST while daily minimum was just below $200 \mathrm{~m}$ between 00:00 and 06:00 CST. The comparison of observed and model PBL height is shown at Fig. 6. Our results indicated that the model tended to overpredict the daily maximum PBL height; obs-nudging helped to reduce the overprediction. For the daily minimum PBL height, No-OA case had slightly high biases while the OA case matched quite well with in situ height data. The observed minimum PBL height was lower than that reported by Haman et al. (2012), which is likely due to the cloudy conditions prevailing in September 2013. There was no apparent explanation on the reduced daytime PBL biases in the OA case than the base case, but it is likely the results of improved winds and temperatures in the PBL.

\subsubsection{Cold front passage}

The surface winds on 20 September were overwhelmingly southerly in the region and reversed on 21 September due to the arrival of a cold front. The hour-by-hour wind shifts for 11 sites in HGB on 21 September are plotted in Fig. 7. The sites are sorted by latitude with the southernmost site, Galveston $\mathrm{C} 1034$, located at the bottom row. There was only one site, Deer Park C35, showing weak southerly at 00:00 CST while all the others had mostly weak northerly. Starting from 01:00 CST, winds in the entire HGB area turned northerly to northeasterly and continued gaining strength in the next few hours, indicating cold air had taken over the region.

Both cases performed reasonably well on 21 September and the timing of wind shift was captured accurately, although No-OA lagged behind by $\sim 1 \mathrm{~h}$. The winds turned weak northerly at 00:00 CST for most sites but the NoOA case still showed the wind direction to be all southerly. Besides the timing, the northeasterly winds in the No-OA case sometimes were too strong; obs-nudging helped moderate the winds. The reduced V-WIND bias in $1 \mathrm{Hr}-\mathrm{OA}$ was also evident in the wind model-measurement statistics on 21 September.

\subsection{Ozone}

\subsubsection{Regional average hourly ozone}

Figure 4 plots the regional average hourly ozone, which was defined similarly to the average temperature. Overall, observed ozone concentrations were low and the model did a reasonably good job capturing the timing of intra-day variations. However, both cases tended to overpredict the daily highs and daily lows, especially in the first 8 days and between 15 and 21 September. An obvious departure is the 25 September - both cases underpredicted the daily high. During the model high-bias period, the OA case usually did better in reaching the daily low although it overpredicted the high a bit more than the base case. The nighttime biases were reduced likely because the lower southerly winds in the OA case transported less ozone from the Gulf to the land.

Our results suggested that the modeled ozone concentrations were likely higher in the Gulf than those in the real world. During the periods 2-4 and 7-8 September, the incoming ozone from the Gulf was markedly lower than "normal" values. Since the model ozone had fixed boundary values, the model was unable to capture these daily ozone variations at the boundary. The model showed the highest biases during the period of 19-20 September, which is likely due to overcast skies and uncertainties in models cloud fields and high background ozone values. Despite the overprediction, the biases in OA case are notably lower than the base NoOA case during the nights of 19 and 20 September. A future study to upgrade the accuracy of cloud fraction using remote sensing data (e.g., Moderate Resolution Imaging Spectroradiometer, or MODIS) should be helpful in explaining the biases.

There were a few days with elevated ozone due to postfront meteorology conditions. The only exceedance happened on 25 September, which was likely caused by meteorological events in Houston and the Galveston Bay. The overall ozone on 26 September was higher than normal after southerly winds transported the ozone back from the Gulf, raising ozone concentrations over the entire region. A more detailed analysis of model predictions on 25 September will be presented in Sect. 5.2.3. 

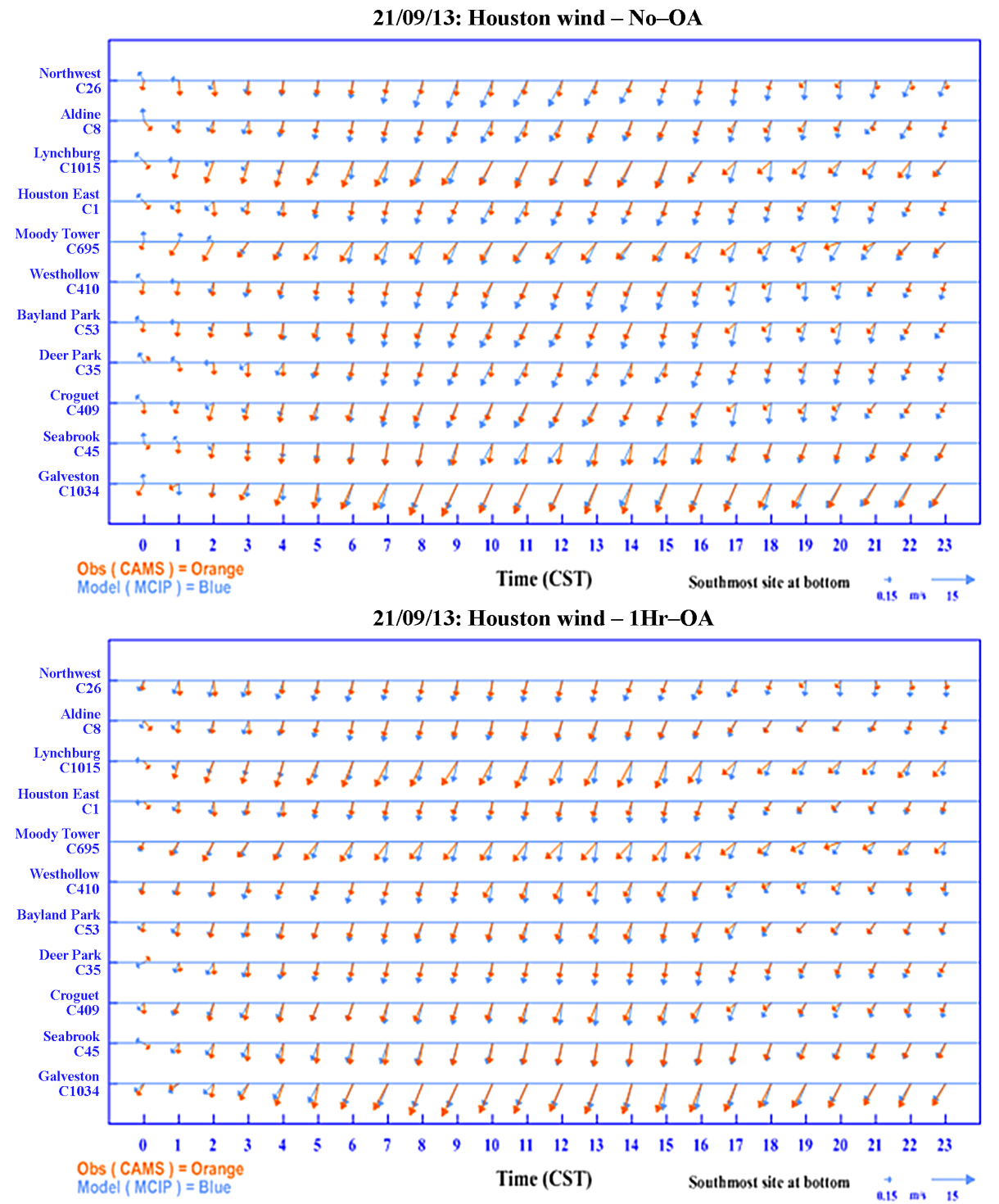

Figure 7. Hourly model (blue) and CAMS (orange) winds at 11 sites on 21 September: No-OA (top panel) and 1Hr-OA (bottom panel). The 1Hr-OA case is better at 00:00 to 02:00 CST and 17:00 to 20:00 CST.

\subsubsection{Performance statistics}

The ozone statistics are listed in Table 4. Both cases had very similar correlations of 0.72 and 0.73 . However, the mean biases in the OA case were lower than the base case by $3.2 \mathrm{ppb}$, which helped raise the IOA from 0.78 to 0.83 . The model standard deviation increased in the OA case and matched better with that of the in situ data. The IOA improvement of the $1 \mathrm{Hr}-\mathrm{OA}$ case over the base case for ozone was slightly less as compared to that for temperature and winds.

\subsubsection{High-ozone episode after the passage of a front}

In SETX, high-ozone events during the fall season usually occurred after the passage of a cold front (e.g., Rappenglück et al., 2008; Ngan and Byun, 2011; Ngan et al., 2012; Haman et al., 2014). Two factors may have contributed to the postfront ozone events: (1) following a cold spell, light winds and sunny skies create an ideal condition for ozone production and accumulation; (2) wind reversal may transport back the pollutants that were previously blown into the Gulf.

During the DISCOVER-AQ period, the two days with highest ozone concentrations were 25 and 26 September as indicated in Fig. 4. The $1 \mathrm{~h}$ maximum ozone on 25 September was localized and higher by about $40 \mathrm{ppb}$ than 26 September. In addition to heightened background ozone on 25 September, the major contributor was the production resulting from favorable weather conditions: sunny, overall light winds, and shifting winds over the industrial area. The light morning 
Table 4. Statistics of ozone for CMAQ simulations; see Table 3 for column header information.

\begin{tabular}{lcccccccccc}
\hline Case & $N$ & Corr & IOA & RMSE & MAE & MB & O_M & M_M & O_SD & M_SD \\
\hline No-OA & 33308 & 0.72 & 0.78 & 14.9 & 12.3 & 9.3 & 24.4 & 33.7 & 16.5 & 14.1 \\
1Hr-OA & 33308 & 0.73 & 0.83 & 13.8 & 11.0 & 6.1 & 24.4 & 30.6 & 16.5 & 17.4 \\
\hline
\end{tabular}

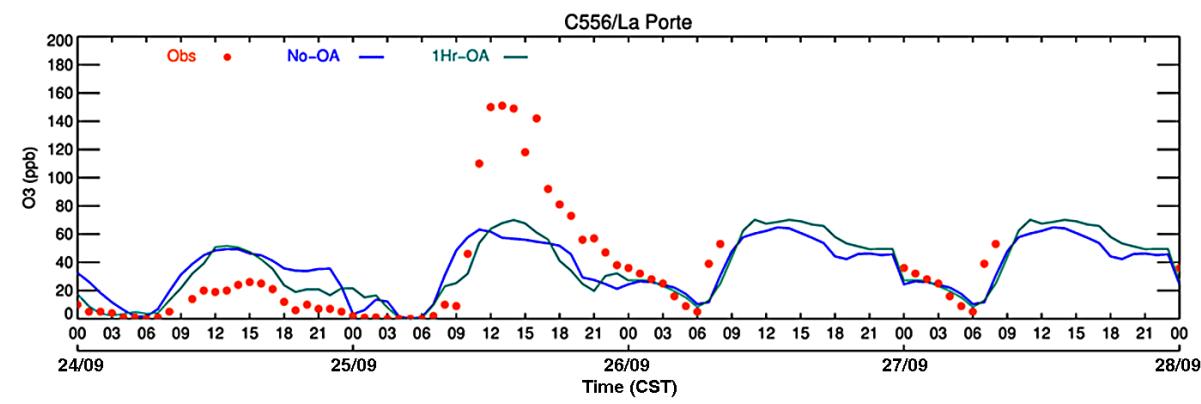

Figure 8. Ozone time series of La Porte (C556) between 00:00 CST on 24 September and 00:00 CST on 28 September 2013.

land breeze carried pollutants from the ship channel area to the Galveston Bay. As the day warmed up, the bay breeze started to develop and carry pollutants back to the land. This localized circulation was described by Banta et al. (2005). Ngan et al. (2012) reported the same phenomenon in their Texas Air Quality Study-II 2006 study.

Figure 8 shows the ozone time series for the La Porte (C556 in Fig. 1) site located in the HSC area. The highest hourly ozone for September, $151 \mathrm{ppb}$ occurred here at 13:00 CST on 25 September. Ozone rose from 10 to $150 \mathrm{ppb}$ between 09:00 and 12:00 CST. Such a sharp increase in ozone was likely the result of increased photochemical activity under favorable meteorological conditions in an area with accumulated precursors. Figures 9 and 10 depict the wind and ozone concentrations at 08:00 and 13:00 CST.

The wind plots of Fig. 9 indicate that the observed winds in the HGB region at 08:00 CST were light northerly for sites located on the northern side, while they were westerly in the middle and south. The base case winds were all northerly while the OA case had northwesterly winds for the northern side and westerly winds for the middle and south. Hence, the model winds in OA case are more realistic than the winds in the base case. The 09:00 CST winds were similar to those of 08:00 CST. As a result, the ozone statistics in Table 5 showed that the OA case had much better correlation and IOA than the base case during 08:00-09:00 CST. This example demonstrated the ability of obs-nudging to correct erroneous winds. However, later events showed it may not always be able to perform consistently.

The bay breeze started to develop at 10:00 CST near the C556 site. The early onset was likely to be related to warming up on the previous afternoon on 24 September as indicated in Fig. 3. At 10:00 CST most other sites to the west of HSC experienced light northwesterly winds while those at
Table 5. Statistics of ozone on 25 September 2013, all day and hours 0 to 13 . Both correlation and index of agreement are unitless. The bold numbers indicate the $3 \mathrm{~h}$ (07:00 to 09:00 CST) when the ozone in $1 \mathrm{Hr}-\mathrm{OA}$ case is significantly better than the No-OA case due to much improved winds.

\begin{tabular}{lcrrrrrr}
\hline & & \multicolumn{2}{c}{ No-OA } & & \multicolumn{2}{c}{ 1Hr-OA } \\
\cline { 3 - 4 } \cline { 7 - 8 } & $N$ & Corr & IOA & & Corr & IOA \\
\hline Hr/All & 1150 & 0.79 & 0.86 & & 0.81 & 0.88 \\
0 & 48 & 0.04 & 0.30 & & 0.40 & 0.46 \\
1 & 43 & 0.20 & 0.24 & & 0.36 & 0.30 \\
2 & 48 & & 0.14 & 0.25 & & 0.35 & 0.35 \\
3 & 48 & 0.19 & 0.30 & & 0.32 & 0.35 \\
4 & 48 & 0.27 & 0.36 & & 0.31 & 0.35 \\
5 & 47 & 0.24 & 0.36 & & 0.28 & 0.37 \\
6 & 47 & 0.33 & 0.38 & & 0.35 & 0.37 \\
7 & 48 & 0.06 & 0.39 & & 0.29 & 0.47 \\
$\mathbf{8}$ & $\mathbf{4 8}$ & $\mathbf{0 . 0 9}$ & $\mathbf{0 . 4 3}$ & & $\mathbf{0 . 5 3}$ & $\mathbf{0 . 6 3}$ \\
$\mathbf{9}$ & $\mathbf{4 7}$ & $\mathbf{0 . 0 5}$ & $\mathbf{0 . 4 1}$ & & $\mathbf{0 . 5 5}$ & $\mathbf{0 . 7 4}$ \\
10 & 47 & -0.10 & 0.29 & & 0.30 & 0.51 \\
11 & 47 & 0.13 & 0.39 & & -0.07 & 0.36 \\
12 & 49 & 0.09 & 0.38 & & 0.25 & 0.40 \\
13 & 49 & -0.09 & 0.37 & & 0.36 & 0.46 \\
\hline
\end{tabular}

HSC originated from the northeast. Combined with the easterly bay breeze, a convergence zone was formed just below C556, where emissions from the HSC area stalled and accumulated. At 13:00 CST, the whole region had light winds and the bay breeze was well developed. The highest ozone indeed appeared in C556 and its vicinity. The rapid increase of ozone concentration for C556 between 09:00 and 13:00 CST is shown in Fig. 8. 


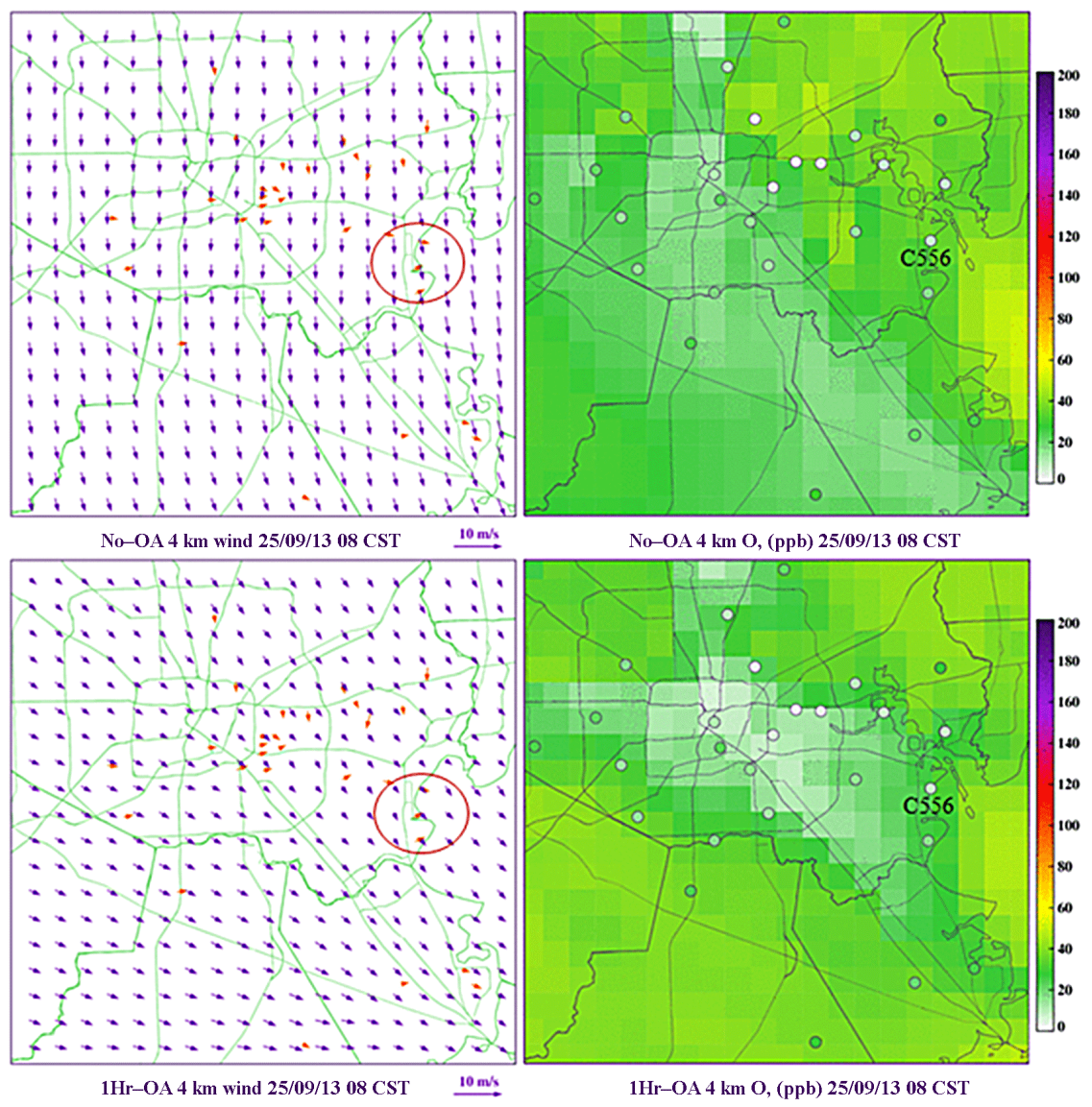

Figure 9. Zoom-in ozone concentrations (right panels) and wind plots (left panels) at 13:00 CST on 25 September for No-OA (top panels) and 1Hr-OA (bottom panels). Ozone observation is in the small circle; wind observation is indicated by an orange arrow. La Porte site C556 is labeled. The numerical range of the right-side color scale is 0 to $200 \mathrm{ppb}$. Higher values than $200 \mathrm{ppb}$ have the same color as $200 \mathrm{ppb}$.

It is important to note that both modeled cases missed the wind shifts in the HSC area and the resulting convergence zone near C556. This could explain the model's inability to recreate the sharp ozone increase at C556. Figure 9 shows that the ozone concentrations around HSC area are quite low $(\sim 10 \mathrm{ppb})$ at 08:00 CST. A further examination showed that while both model cases missed the wind shift and convergence, the patterns were different. The base case winds differed considerably from the observed ones for most of the morning: instead of a weak westerly, it had stronger northwesterly to northerly winds. By 08:00 CST, winds were almost uniformly northerly in the base case while they were weak west-northwesterly in the OA case (Fig. 9). The oval in Fig. 9's top-left panel shows the mismatch of winds around C556 in the base case. As a result, the $\mathrm{NO}_{x}$ produced in the city was carried further to the southeast in the model in the base case. Until 13:00 CST, base case winds did not shift directions by much. The OA case got the early hour weak northwesterly right but missed the bay breeze onset between 10:00 and 13:00 CST (oval in Fig. 10). The OA case could not reproduce the small-scale wind reversal near C556, sug- gesting there is a limitation in the current WRF OA's capability to rectify the winds when poorly simulated. However, the OA case did improve the spatial ozone pattern, as the highozone area was closer to HSC after OA (Fig. 10).

The ozone measurements from aircraft P3-B provided a more complete picture for the ozone evolution on 25 September. During the day, the aircraft flew around the industrial area, Galveston Bay, and Galveston Island for about $9 \mathrm{~h}$. Figures 11 and 12 plot the ozone concentrations along the aircraft tracks at 08:00 and 13:00 CST. Surface layer ozone from the No-OA case is provided as background for reference. At 08:00 CST, an ozone level of 60-80 ppb aloft was already observed at three locations (three loops in Fig. 11): Galveston Island, Smith Point, and the inner city. Another high of $\sim 90 \mathrm{ppb}$ could be seen above the HSC area. Ozonesonde observations over HGB showed the aloft ozone concentrations were typically $\sim 40-60$ ppb (e.g., Li and Rappenglück, 2014) at the height level of a few hundred meters to $4 \mathrm{~km}$. The higher-than-normal ozone aloft suggested a postfront ozone recirculation condition. Such high ozone aloft might raise surface ozone as a growing PBL downwardly 

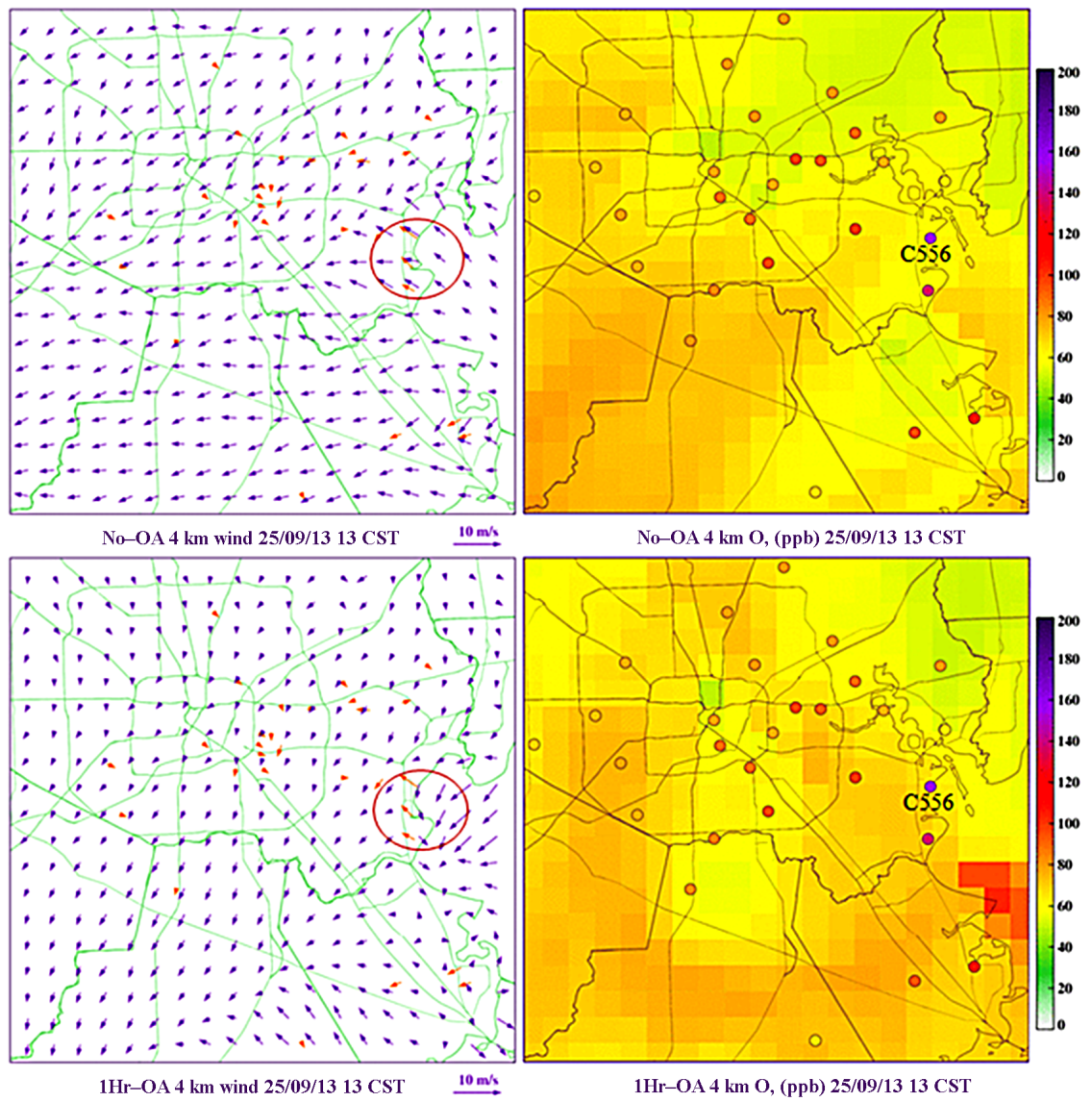

Figure 10. Zoom-in ozone concentrations (right panels) and wind plots (left panels) at 13:00 CST on 25 September for No-OA (top panels) and $1 \mathrm{Hr}-\mathrm{OA}$ (bottom panels). Ozone observation is in the small circle; wind observation is indicated by an orange arrow. Bay breeze is shown in the orange oval. The numerical range of the right-side color scale is 0 to $200 \mathrm{ppb}$. Higher values than $200 \mathrm{ppb}$ have the same color as $200 \mathrm{ppb}$.

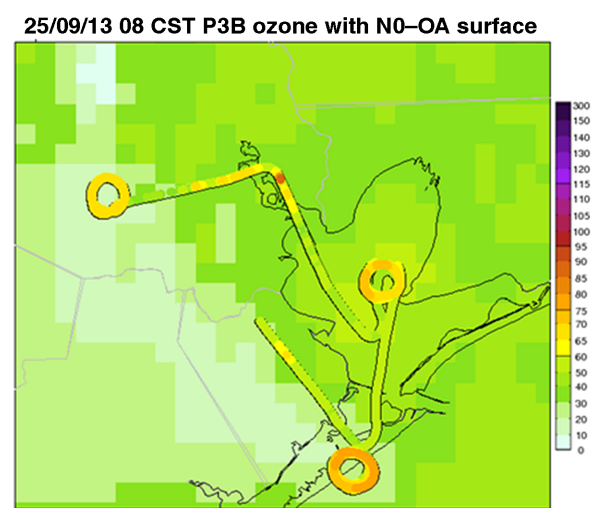

Figure 11. Ozone along aircraft tracks at 08:00 CST on 25 September, overlaid upon model No-OA surface ozone. The numerical range of the right-side color scale is 0 to $300 \mathrm{ppb}$. Higher values than $300 \mathrm{ppb}$ have the same color as $300 \mathrm{ppb}$.

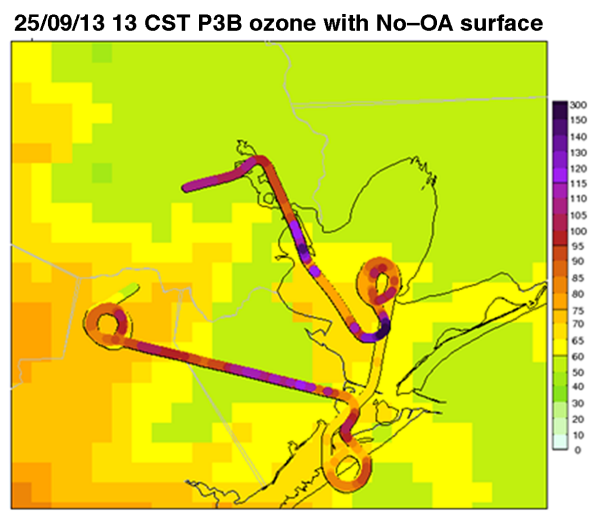

Figure 12. Ozone along aircraft tracks on 25 September at 13:00 CST, overlaid upon model No-OA surface ozone. Plumes can be seen as dark purple circles in Galveston Bay. The numerical range of the right-side color scale is 0 to $300 \mathrm{ppb}$. Higher values than $300 \mathrm{ppb}$ have the same color as $300 \mathrm{ppb}$. 

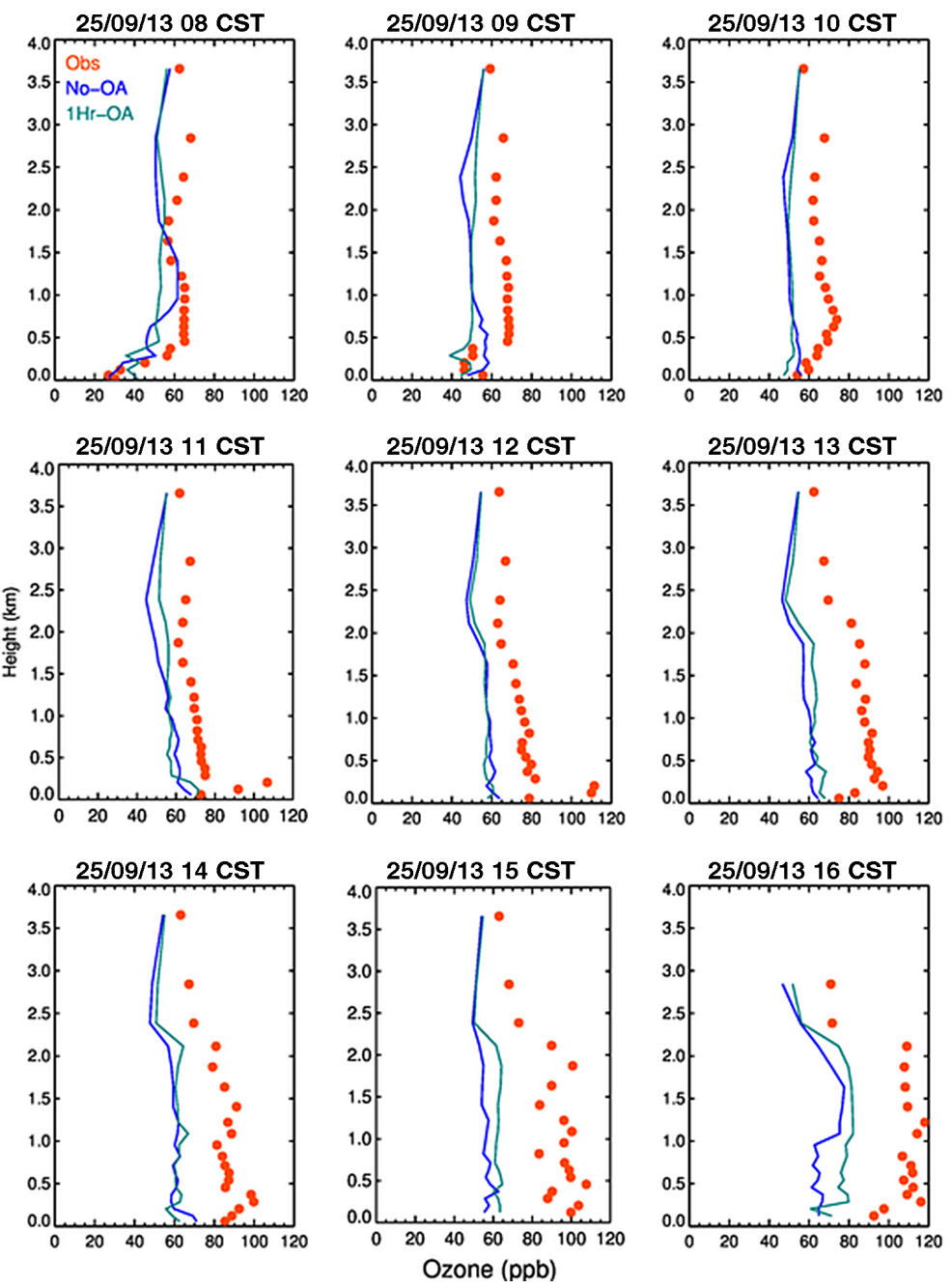

Figure 13. Vertical ozone profiles from 08:00 to 16:00 CST on 25 September 2013 for two cases of No-OA and 1Hr-OA compared with corresponding observations. There are nine plots, each for $1 \mathrm{~h}$, with date and hour as caption.

mixed the air aloft with near surface air. At 13:00 CST, high ozone over $100 \mathrm{ppb}$ was observed at multiple locations. The highest aloft ozone of $\sim 160 \mathrm{ppb}$ occurred southwest of Smith Point in the Galveston Bay. Such a large increase in ozone concentrations was likely the result of active photochemistry in the industrial zone and around Galveston Bay, indicating a high level of precursor accumulation in the area.

Figure 13 shows hourly ozone vertical profiles from 08:00 to 16:00 CST on 25 September, with ozone being displayed on the $x$ axis and height on the $y$ axis. The observed ozone was averaged over multiple measurements in the same model cell, so that they could be compared to model output. Next, both model and observed ozone values were averaged over all the grid cells in the same model layer, such that one dot represents the average ozone of all the cells in the same layer. The 08:00 and 09:00CST profiles showed there was a high-ozone layer with average ozone of $\sim 65 \mathrm{ppb}$ stretching from 450 to $1200 \mathrm{~m}$ in height. In comparison, all model runs had lower ozone in this layer. The model biases as shown in Fig. 14 were about -10 ppb at 08:00 CST and grew to $-20 \mathrm{ppb}$ at 09:00 CST. The large discrepancy between low surface ozone and ozone aloft was unusual and may be explained by the arrival of a high-ozone air mass from aloft. The observed ozone rose continuously in the following hours; however, simulated ozone stagnated around $60 \mathrm{ppb}$ from the surface up to $2000 \mathrm{~m}$ until 15:00 CST. At 16:00 CST, the ozone of the OA case in the lowermost $(0$ $1 \mathrm{~km}$ ) layer rose $20 \mathrm{ppb}$ over the previous hours yet the base case ozone increased only a few ppb. Although different in magnitude, the aloft ozone had a few similar features to the surface ozone. Firstly, the model missed the observed high ozone in the afternoon by a large margin. For example, the base case underpredicted the $0-1 \mathrm{~km}$ level ozone by up to $50 \mathrm{ppb}$. The primary cause for the lower ozone production was likely the models wind fields as both model and observations had a clear sky in the industrial area and the Galve- 

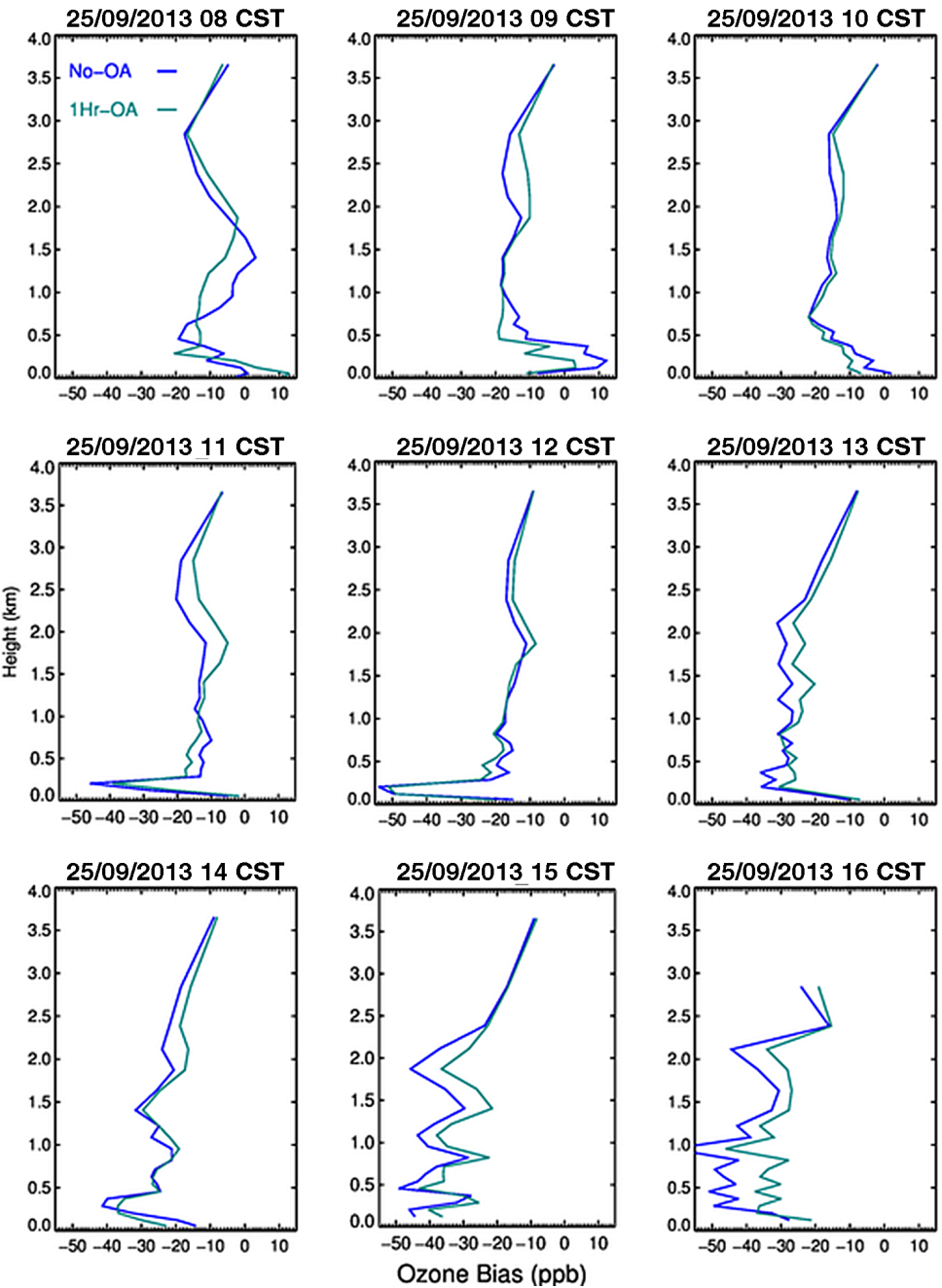

Figure 14. Model vertical ozone biases from 08:00 to 16:00 CST on 25 September 2013 for two cases of No-OA and 1Hr-OA. There are nine plots, each for $1 \mathrm{~h}$, with date and hour as caption.

ston Bay. Secondly, nudging clearly helped reduce the ozone biases aloft. In most of the plots in Fig. 14, the OA case had lower biases than the base case. The largest difference was at 16:00 CST when nudging reduced biases from $\sim 45$ to $\sim 30 \mathrm{ppb}$ in the $300-1000 \mathrm{~m}$ layer.

While it is easy to understand the improvements in temperature and winds after obs-nudging was applied, it is more difficult to explain how other variables such as precipitation and clouds reacted to obs-nudging. The indirect impact of these meteorological variables on ozone was harder to assess. In our study, we did not evaluate clouds quantitatively as there were no digitized cloud fraction data available for our modeling domains. A preliminary analysis on convection showed that there were occasions in which the model missed the convection or precipitation and there were other occasions in which the model created artificial convection. The convection cells were usually visible as a "star burst" from surface wind vector plots - arrows going out to differ- ent directions from a center. However, the mismatch in convection appeared to be not a serious issue since only a few occurrences were observed in the month of September.

\section{Conclusions and discussions}

In this study, we performed two WRF and CMAQ model simulations to explore model sensitivity to observation nudging. In evaluating meteorological and ozone conditions, we found that obs-nudging improved the meteorology and ozone performance as shown in the IOA of temperature, winds, and ozone. While the base case winds were overall well simulated, obs-nudging significantly reduced the high wind biases (especially the meridional wind) shown in the base case. For planetary boundary layer height, obs-nudging reduced high biases in both daily maximum and daily minimum values. In the end, the combined changes in meteorology lowered the ozone biases by about $3 \mathrm{ppb}$, a $35 \%$ reduction. 
There were short time periods (such as between 07:00 and 09:00 CST on 25 September 2013) when the simulated base case model winds differed significantly from observational data and obs-nudging significantly corrected the meteorological simulation problems, leading to much better ozone simulation. However, model ozone biases are also impacted by emissions and lateral boundary conditions.

The only high-ozone episode in the simulation period was related to the cold front passage. The small-scale winds and high aloft ozone concentrations on 25 September likely contributed to the ozone exceedance in the area. It is also possible that an unreported emission event played a role. Since the maximum surface ozone at La Porte was much higher than the morning-time ozone aloft, the active local ozone production was likely the dominant factor. Analyses of ozone aloft on 25 September showed while there was high ozone aloft and large negative model biases, the OA case tended to have smaller biases, especially in late hours of the day.

Small-scale meteorological events such as wind transition and recirculation have been cited (e.g., Banta et al., 2005; Darby, 2005) for their contributions to high-ozone events. The model capability in reproducing these events is critical in simulating such high-ozone episodes. The base case did not recreate the 25 September small-scale events likely due to the complex winds and a lack of local information which can be used to steer model state closer to reality. However, the inability of the sensitivity case to replicate the local winds is likely a result of the shortcomings of the nudging process pending further investigation. An ongoing study by the current authors suggests that errors in the meteorological fields from the default grid nudging files are important sources. Methods are being tested to improve the quality of the grid nudging files. Early results showed that the bay breeze which caused the wind reversal around La Porte was well captured through improved grid nudging files. In addition, more observational data (e.g., more sites and higher data frequency) and more testing on the combination of nudging settings should help improve the obs-nudging performance. Also, the impact of obs-nudging on precipitation and clouds should be further investigated to understand their effect on chemistry.

Acknowledgements. The authors thank Texas Air Research Center (TARC) for its support through grant number 413UHH0144A and Air Quality Research Program (AQRP) through 14-014, the DISCOVER-AQ team for the aircraft data, Vanessa Caicedo for LIDAR data, and the TCEQ CAMS site team for the in situ ozone and meteorological data.

Edited by: W. Lahoz

\section{References}

Banta, R. M., Senff, C. J., White, A. B., Trainer, M., McNider, R. T., Valente, R. J., Mayor, S. D., Alvarez, R. J., Hardesty, R. M., and Parrish, D.: Daytime buildup and nighttime transport of urban ozone in the boundary layer during a stagnation episode, J. Geophys. Res.-Atmos., 103, 22519-22544, 1998.

Banta, R. M., Senff, C. J., Nielsen-Gammon, J., Darby, L. S., Ryerson, T. B., Alvarez, R. J., Sandberg, S. R., Williams, E. J., and Trainer, M.: A bad air day in Houston, B. Am. Meteorol. Soc., 86, 657-669, doi:10.1175/bams-86-5-657, 2005.

Banta, R. M., Senff, C. J., Alvarez, R. J., Langford, A. O., Parrish, D. D., Trainer, M. K., Darby, L. S., Hardesty, R. M., Lambeth, B., Neuman, J. A., Angevine, W. M., Nielsen-Gammon, J., Sandberg, S. P., and White, A. B.: Dependence of daily peak $\mathrm{O}_{3}$ concentrations near Houston, Texas on environmental factors: Wind speed, temperature, and boundary-layer depth, Atmos. Environ., 45, 162-173, doi:10.1016/j.atmosenv.2010.09.030, 2011.

Byun, D. and Schere, K. L.: Review of the governing equations, computational algorithms, and other components of the models3 Community Multiscale Air Quality (CMAQ) modeling system, Appl. Mech. Rev., 59, 51-77, doi:10.1115/1.2128636, 2006.

Byun, D., Ngan, F., Li, X., Lee, D., and Kim, S.: Analysis of Air Pollution Events in Summer 2006 and Preparation of Model Input Data for the Assessment Study, Grant No. 582-5-64594FY07-02, Final Report, Evaluation of Retrospective MM5 and CMAQ Simulations of TexAQS-II Period with CAMS Measurements, Texas Commission on Environmental Quality, Austin, Texas, USA, 25 pp., 2008,

Cheng, F. Y. and Byun, D.: Application of high resolution land use and land cover data for atmospheric modeling in the Houston-Galveston metropolitan area, Part I: Meteorological simulation results, Atmos. Environ., 42, 7795-7811, doi:10.1016/j.atmosenv.2008.04.055, 2008.

Cheung, V. T. and Wang, T.: Observational study of ozone pollution at a rural site in the Yangtze Delta of China, Atmos. Environ., 35, 4947-4958, 2001.

Choi, Y.: The impact of satellite-adjusted $\mathrm{NO}_{x}$ emissions on simulated $\mathrm{NO}_{x}$ and $\mathrm{O}_{3}$ discrepancies in the urban and outflow areas of the Pacific and Lower Middle US, Atmos. Chem. Phys., 14, 675-690, doi:10.5194/acp-14-675-2014, 2014.

Choi, Y. and Souri, A.: Chemical condition and surface ozone in large cities of Texas during the last decade: observational evidence from OMI, CAMS, and Model Analysis, Remote Sens. Environ., 168, 90-101, doi:10.1016/j.rse.2015.06.026, 2015.

Choi, Y., Kim, H., Tong, D., and Lee, P.: Summertime weekly cycles of observed and modeled $\mathrm{NO}_{x}$ and $\mathrm{O}_{3}$ concentrations as a function of satellite-derived ozone production sensitivity and land use types over the Continental United States, Atmos. Chem. Phys., 12, 6291-6307, doi:10.5194/acp-12-6291-2012, 2012.

Cuchiara, G. C., Li, X., Carvalho, J., and Rappenglück, B.: Intercomparison of planetary boundary layer parameterization and its impacts on surface ozone concentration in the WRF/chem model for a case study in Houston, Texas, Atmos. Environ., 96, 175185, doi:10.1016/j.atmosenv.2014.07.013, 2014.

Czader, B. H., Li, X. S., and Rappenglueck, B.: CMAQ modeling and analysis of radicals, radical precursors, and chemical transformations, J. Geophys. Res.-Atmos., 118, 11376-11387, doi:10.1002/Jgrd.50807, 2013. 
Czader, B. H., Choi, Y., Li, X., Alvarez, S., and Lefer, B.: Impact of updated traffic emissions on HONO mixing ratios simulated for urban site in Houston, Texas, Atmos. Chem. Phys., 15, 12531263, doi:10.5194/acp-15-1253-2015, 2015.

Darby, L. S.: Cluster analysis of surface winds in Houston, Texas, and the impact of wind patterns on ozone, J. Appl. Meteorol., 44, 1788-1806, doi:10.1175/jam2320.1, 2005.

Daum, P. H., Kleinman, L. I., Springston, S. R., Nunnermacker, L. J., Lee, Y. N., Weinstein-Lloyd, J., Zheng, J., and Berkowitz, C. M.: Origin and properties of plumes of high ozone observed during the Texas 2000 Air Quality Study (TexAQS 2000), J. Geophys. Res.-Atmos., 109, D17306, doi:10.1029/2003jd004311, 2004.

Deng, A., Stauffer, D., Gaudet, B., Dudhia, J., Hacker, J., Bruyere, C., Wu, W., Vandenberghe, F., Liu, Y., and Bourgeois, A.: Update on WRF-ARW End-to-end Multi-scale FDDA System, 10th WRF Users' Workshop, NCAR, Boulder, CO, 2009.

Diao, L., Roy, A., Czader, B., Pan, S., Jeon, W., Souri, A. H., and Choi, Y.: Modeling the effect of relative humidity on nitrous acid formation in the Houston area, Atmos. Environ., 131, 78-82, 2016.

Foley, K. M., Roselle, S. J., Appel, K. W., Bhave, P. V., Pleim, J. E., Otte, T. L., Mathur, R., Sarwar, G., Young, J. O., Gilliam, R. C., Nolte, C. G., Kelly, J. T., Gilliland, A. B., and Bash, J. O.: Incremental testing of the Community Multiscale Air Quality (CMAQ) modeling system version 4.7, Geosci. Model Dev., 3, 205-226, doi:10.5194/gmd-3-205-2010, 2010.

Gilliam, R. C. and Pleim, J. E.: Performance Assessment of New Land Surface and Planetary Boundary Layer Physics in the WRF-ARW, J. Appl. Meteorol. Clim., 49, 760-774, doi:10.1175/2009jamc2126.1, 2010.

Haman, C. L., Lefer, B., and Morris, G. A.: Seasonal Variability in the Diurnal Evolution of the Boundary Layer in a Near-Coastal Urban Environment. J. Atmos. Ocean Tech., 29, 697-710, 2012.

Haman, C. L., Couzo, E., Flynn, J. H., Vizuete, W., Heffron, B., and Lefer, B. L.: Relationship between boundary layer heights and growth rates with ground-level ozone in Houston, Texas, J. Geophys. Res.-Atmos., 119, 6230-6245, 2014.

Houyoux, M., Vukovich, J., and Brandmeyer, J.: Sparse Matrix Kernel Emissions Modeling System: SMOKE User Manual. MCNCNorth Carolina Supercomputing Center. Available at: https:// cmascenter.org/smoke/ (last access: February 2016), 2000.

Huang, X.-Y., Xiao, Q., Barker, D. M., Zhang, X., Michalakes, J., Huang, W., Henderson, T., Bray, J., Chen, Y., and Ma, Z.: Fourdimensional variational data assimilation for WRF: Formulation and preliminary results, Mon. Weather Rev., 137, 299-314, 2009.

Kleinman, L. I., Daum, P. H., Lee, Y. N., Nunnermacker, L. J., Springston, S. R., Weinstein-Lloyd, J., and Rudolph, J.: Ozone production efficiency in an urban area, J. Geophys. Res.-Atmos., 107, 4733, doi:10.1029/2002jd002529, 2002.

Le Dimet, F. X. and Talagrand, O.: Variational algorithms for analysis and assimilation of meteorological observations: theoretical aspects, Tellus A, 38, 97-110, 1986.

Lefer, B. and Rappengluck, B.: The TexAQS-II radical and aerosol measurement project (TRAMP) Preface, Atmos. Environ., 44, 3997-4004, doi:10.1016/j.atmosenv.2010.05.053, 2010.

Li, X. and Rappenglück, B.: A WRF-CMAQ study on spring time vertical ozone structure in Southeast Texas, Atmos. Environ., 97, 363-385, doi:10.1016/j.atmosenv.2014.08.036, 2014.
Li, X., Lee, D., Kim, S.-T., Kim, H., Ngan, F., Cheng, F., and Byun, D.: Performance Evaluation of a Year-long Run of an Air Quality Forecasting System for Southeast Texas, 10th Conference on Atmospheric Chemistry, January 2008, New Orleans, 2008.

Liu, Y., Bourgeois, A., Warner, T., Swerdlin, S., and Hacker, J.: An implementation of observation nudging-based FDDA into WRF for supporting ATEC test operations, 2005 WRF user workshop, Boulder, CO, 2005.

Liu, Y., Bourgeois, A., Warner, T., Swerdlin, S., and Yu, W.: An update on "observation nudging"-based FDDA for WRF-ARW: Verification using OSSE and performance of real-time forecasts, 2006 WRF user workshop, Boulder, CO, 2006.

Mason, R.; Strum, M., and Houyoux, M.: Technical Support Document (TSD) Preparation of Emissions Inventories for the Version 4, 2005-based Platform, US Environmental Protection Agency, Office of Air and Radiation, Office of Air Quality Planning and Standards, Air Quality Assessment Division, Research Triangle Park, North Carolina, USA, 2010.

Ngan, F. and Byun, D.: Classification of Weather Patterns and Associated Trajectories of High-Ozone Episodes in the HoustonGalveston-Brazoria Area during the 2005/06 TexAQS-II, J. Appl. Meteorol. Clim., 50, 485-499, doi:10.1175/2010jamc2483.1, 2011.

Ngan, F., Byun, D., Kim, H., Lee, D., Rappengluck, B., and Pour-Biazar, A.: Performance assessment of retrospective meteorological inputs for use in air quality modeling during TexAQS 2006, Atmos. Environ., 54, 86-96, doi:10.1016/j.atmosenv.2012.01.035, 2012.

Olaguer, E. P., Rappengluck, B., Lefer, B., Stutz, J., Dibb, J., Griffin, R., Brune, W. H., Shauck, M., Buhr, M., Jeffries, H., Vizuete, W., and Pinto, J. P.: Deciphering the Role of Radical Precursors during the Second Texas Air Quality Study, J. Air Waste Manage. Assoc., 59, 1258-1277, doi:10.3155/1047-3289.59.11.1258, 2009.

Otte, T. L.: The impact of nudging in the meteorological model for retrospective air quality simulations. Part I: Evaluation against national observation networks, J. Appl. Meteorol. Clim., 47, 1853-1867, doi:10.1175/2007jamc1790.1, 2008.

Pan, S., Choi, Y., Roy, A., Li, X., Jeon, W., and Souri, A.: Modeling the uncertainty of several VOC and ints impact on simulated VOC and ozone in Houston, Texas, Atmos. Environ., 120, 404416, 2015

Parrish, D. D., Allen, D. T., Bates, T. S., Estes, M., Fehsenfeld, F. C., Feingold, G., Ferrare, R., Hardesty, R. M., Meagher, J. F., Nielsen-Gammon, J. W., Pierce, R. B., Ryerson, T. B., Seinfeld, J. H., and Williams, E. J.: Overview of the Second Texas Air Quality Study (TexAQS II) and the Gulf of Mexico Atmospheric Composition and Climate Study (GoMACCS), J. Geophys. Res.Atmos., 114, D00F13, doi:10.1029/2009jd011842, 2009.

Pour-Biazar, A., McNider, R. T., Roselle, S. J., Suggs, R., Jedlovec, G., Byun, D. W., Kim, S., Lin, C. J., Ho, T. C., Haines, S., Dornblaser, B., and Cameron, R.: Correcting photolysis rates on the basis of satellite observed clouds, J. Geophys. Res.-Atmos., 112, D10302, doi:10.1029/2006jd007422, 2007.

Rappenglück, B., Perna, R., Zhong, S. Y., and Morris, G. A.: An analysis of the vertical structure of the atmosphere and the upper-level meteorology and their impact on surface ozone levels in Houston, Texas, J. Geophys. Res.-Atmos., 113, D17315, doi:10.1029/2007jd009745, 2008. 
Rappenglück, B., Lefer, B., Mellqvist, J., Czader, B., Golovko, J., Li, X., Alvarez, S., Haman, C., and Johansson, J.: University of Houston Study of Houston Atmospheric Radical Precursors (SHARP), Report to the Texas Commission on Environmental Quality, Texas Commission on Environmental Quality, Austin, Texas, USA, 145 pp., 2011.

Rogers, R. E., Deng, A. J., Stauffer, D. R., Gaudet, B. J., Jia, Y. Q., Soong, S. T., and Tanrikulu, S.: Application of the Weather Research and Forecasting Model for Air Quality Modeling in the San Francisco Bay Area, J. Appl. Meteorol. Clim., 52, 19531973, 2013.

Skamarock, W. C., Klemp, J. B., Dudhia, J., Gill, D. O., Barker, M., Duda, K. G., Huang, Y., Wang, W., and Powers, J. G.: A description of the Advanced Research WRF Version 3, Boulder, Colorado, USA, 1-113, 2008.

Souri, A. H., Choi, Y., Li, X., Kotsakis, A., and Jiang, X.: A 15-year climatology of wind pattern impacts on surface ozone in Houston, Texas, Atmos. Res., doi:10.1016/j.atmosres.2016.02.007, in press, 2016.

Stauffer, D. R. and Seaman, N. L.: Use of 4-dimensional data assimilation in a limited-area mesoscale model. 1. Experiments with synoptic-scale data, Mon. Weather Rev., 118, 1250-1277, 1990.
Stauffer, D. R. and Seaman, N. L.: Multiscale 4-dimensional data assimilation, J. Appl. Meteorol., 33, 416-434, 1994.

Tucker, S. C., Banta, R. M., Langford, A. O., Senff, C. J., Brewer, W. A., Williams, E. J., Lerner, B. M., Osthoff, H. D., and Hardesty, R. M.: Relationships of coastal nocturnal boundary layer winds and turbulence to Houston ozone concentrations during TexAQS 2006, J. Geophys. Res.-Atmos., 115, D10304, doi:10.1029/2009JD013169, 2010.

USEPA - US Environmental Protection Agency, Office of Transportation and Air Quality: Motor Vehicle Emission Simulator (MOVES) User Guide for MOVES2014a, EPA-420B-15-095, http://www3.epa.gov/otaq/models/moves/documents/ 420b15095.pdf (last access: February 2016) 2015.

Willmott, C. J.: On the Validation of Models, Phys. Geogr., 2, 184194, doi:10.1080/02723646.1981.10642213, 1981.

Zhong, S. Y., In, H. J., and Clements, C.: Impact of turbulence, land surface, and radiation parameterizations on simulated boundary layer properties in a coastal environment, J. Geophys. Res.Atmos., 112, D13110, doi:10.1029/2006jd008274, 2007. 